\title{
Raman Spectroscopy: A Promising Technique for Analyzing Nucleic Acid Refractory to PCR Amplification
}

\author{
Milad Soleimani, Rachel Matar and Maxime Merheb*
}

Department of Biotechnology, American University of Ras Al Khaimah AURAK, Ras Al Khaimah, P.O Box 10021, United Arab Emirates

\begin{abstract}
Ancient DNA (aDNA) refers to the genetic material found in dead paleontological and archeological samples. Being subject to various types of stressors, it undergoes different hydrolytic and oxidative post mortem modifications that result in the formation of DNA lesions. These lesions are found to either block the DNA polymerase during replication or induce nucleotide misincorporations. Besides, aDNA samples occur in minimal quantities; which represents an additional obstacle that researchers have to overcome in order to study aDNA. The earliest major efforts included the use of molecular cloning and polymerase chain reaction (PCR) to amplify aDNA sequences. These techniques were later found to be associated with a number of false results and unauthentic findings. There have been numerous attempts to eliminate the shortcomings of PCR and improve the quality of aDNA through avoiding contamination, repairing lesions, using translesion polymerases, etc. However, the majority of these have failed to yield accurate and specific results. Surfaceenhanced resonance Raman scattering (SERRS), on the other hand, starts in the right foot by introducing a sensitive nonenzymatic approach for the specific detection of single- and double-stranded DNA. The ability of this method to evade DNA degradation is particularly important for not only studying aDNA, but also analyzing DNA refractory to PCR amplification in processed products.
\end{abstract}

Keywords: Degraded DNA, polymerase chain reaction, Raman scattering, surface-enhanced resonance.

\section{INTRODUCTION}

Bacterial cloning, polymerase chain reaction (PCR), and high-throughput sequencing amplify miniscule quantities of DNA $[1,2]$ so that there are a sufficient number of copies available for analysis. However, DNA extracted from ancient samples is often recalcitrant to the aforementioned enzymedriven techniques [3]. This is due to the various hydrolytic and oxidative modifications that DNA molecules undergo within inactive cells [4]. Some modifications do not affect the enzyme's bypass and result in miscoding errors, like cytosine deamination. Other modifications such as abasic sites (a.k.a. AP sites), base mismatches, intermolecular crosslinks, and double-strand breaks are known to block the enzymatic elongation, and are therefore called blocking lesions [5, 6]. Despite the efforts in developing efficient methods to repair DNA lesions, there is no way to examine ancient samples for the presence of target DNA sequences beforehand. Aside from primer extension capture [7] and interstrand crosslink (ICL) repair [8] that are designed to rectify lesions, polymerase engineering is aimed at developing DNA polymerases capable of bypassing lesions. However, even engineered damage-tolerant polymerases are found to be ineffective at bypassing intrastrand lesions and also in the presence of inhibitors [9]. Additionally, repair and

*Address correspondence to the author at the Department of Biotechnology, American University of Ras Al Khaimah AURAK, Ras Al Khaimah, P.O Box 10021, United Arab Emirates; Tel: 009715271133 55;

E-mail: maximemerheb@yahoo.fr breeding techniques are complex, costly, and time consuming with results that are often deemed inconclusive [9-11]. Surface enhanced resonance Raman scattering (SERRS) is a convenient non-enzymatic alternative to the traditional enzymatic methods for the specific detection of DNA. SERRS combines a magnetic amplification of the Raman signal, due to the adsorption of the molecules on a metallic surface, and a resonance effect linked to the use of a chromophore $[12,13]$. It allows the detection of DNA at very low concentration [14]. The recent advances in SERRS to specifically detect single- and double-stranded nucleic acid molecules promise the potential to revolutionize the field of aDNA so much so that sample degradation will no longer be an impediment in recovering the highly covetedbut inscrutable - genetic information of sequences.

\section{DNA DEGRADATION: THE BREACH}

DNA is prone to degradation by a variety of endogenous and exogenous agents [15]. The endogenous agents mainly include nucleases and chemical reactions such as hydrolysis and oxidation. Cell death brings about the rupture of phospholipid membranes and termination of biochemical pathways; whereby the nucleases begin fragmenting the nucleic acid molecules in the cell, causing single- and double-strand breaks [15]. Single-strand breaks, for instanceinduce disintegration of DNA duplex during the denaturation step of PCR [16]. Hydrolysis, on the other hand, results in the generation of abasic sites through depurination and depyrimidination (e.g. removal of uracil by uracil-DNA 
glycosylase) as well as in the deamination of the template bases $[4,5]$. The most common deamination event is that of cytosine to uracil which is a spontaneous hydrolytic reaction involving the release of an amine group [17]. Spontaneous oxidation is the last endogenous source of DNA decay that affects both purines (e.g. guanine to 8-hydroxyguanine) and pyrimidines (e.g. thymine to hydantoin) [3, 4, 18]. Oxidative damages could also occur exogenously by ionizing radiations, resulting in the formation of interstrand crosslinks (ICL) in an oxygen-independent process that involves reaction of a DNA radical with a complementary deoxyadenosine [19]. UV as a non-ionizing radiation is, nevertheless, a potent exogenous stressor giving rise to highly cytotoxic DNA lesions, namely cyclobutanepyrimidine dimers (CPDs) and 6-4 photoproducts (4-6PPs) [20].

Apart from the above classification of DNA damage into endogenous and exogenous with respect to the source of damage, DNA lesions can be conveniently placed into two categories based on their degree of compromise toward replication by polymerases [17]. First, blocking or shortening lesions such as abasic sites, strand breaks, and hydantoins are those that completely resist being bypassed by polymerases and, therefore, thwart replication. Second, non-blocking or miscoding lesions are those that are easily bypassable, albeit more error prone due to the insertion of incorrect nucleotides [10]. The rate and degree of accumulation of DNA damage may vary depending upon the environmental conditions. DNA will survive up to 100,000 years exclusively at $15^{\circ} \mathrm{C}$, neutral $\mathrm{pH}$, and physiological salt concentrations; however, lower temperatures, for instance would slow down degradation and consequently prolong survival [21].

\section{DNA DETECTION: THE CLASSICAL TECHNIQUES}

Investigations of past animal populations by means of extraction, amplification, and sequencing of aDNA obtained from paleontological and archeological samples like fossils, traces from biological sources, museum specimens, have immensely contributed to our understanding of evolution at the molecular level through delving into the phylogenetic relationships of extinct and extant species [22, 23]. The field of aDNA studies is a relatively young one whose wheels were officially set in motion in 1981 by G. Wang and C. Lu, who isolated ancient DNA and RNA from the preserved liver of a corpse found in a 2000-year-old tomb belonging to Han dynasty [24]. With the introduction of gene cloning, the speculations about aDNA were taken one step further. Higuchi and his collaborators extracted DNA sequences from the dried muscular tissue of an extinct species called quagga (Equus quagga) and bulked them up using molecular cloning [25]. The technique was soon after applied to human DNA by Pääbowho, after strenuously examining 23 naturally preserved mummies, detected DNA in a 24,000-year-old mummy of a child [26]. Notwithstanding the partial success, the studies suffered from certain setbacks. First, the origins of the viable DNA isolates were found to essentially trace to bacteria and fungi, rather than the host animals. Second, the endogenous DNA was reported to comprise degraded fragments of multi-copy loci and low molecular weights such as repetitive sequences and mitochondrial DNA. Third, the method cannot be widely employed as it is limited to particularly well-preserved samples.

Ever since its invention in 1984 by the American biochemist Kary Mullis [27], the polymerase chain reaction (PCR) has been routinely and extensively used to retrieve and amplify minimal amounts of DNA. The advent of PCR generated high hopes among those in search of history in the bases of aDNA. Even today, archeologists-like those seeking information on the Dead Sea Scrolls or on the human brains discovered in a Florida sinkhole [28] - use PCR for its convenience, low cost, and the ease with specific sequences which can be recovered from the same sample a number of times [29]. Despite the advantages, PCR presents drawbacks that perturb its reliability in aDNA analysis. One of the drawbacks arises from the inability of polymerases to bypass blocking lesions that involve misinsertions (for example, dAMP opposite abasic sites [30], deletions [31], and ring fragmentation of either the sugar or the base, resulting in inhibition of replication [32]. Another drawback of PCR is its excessive sensitivity to intra-laboratory contamination by exogenous modern DNA. This is especially troublesome with ancient human DNA, in which case both the endogenous sequences and the human contaminant will be inevitably amplified, leading the conclusions astray [29, 33]. The third drawback is the propensity of PCR to misincorporate bases in response to miscoding lesions in aDNA molecules. The lesions appear as two groups of transitions, namely type 1 including adenineto-guanine and the complementary thymine-to-cytosine transitions and type 2 that refers to cytosine-to-thymine and guanine-to-adenine transitions [33]. Cytosine deamination is ultimately responsible for type 2 transitions (which constitute the majority) as the resulting uracil residue mimics a thymine base and consequently the corresponding guanine is erroneously replaced by an adenine [34, 35]. Genealogically, these lesions can lead to artifactual divergences in phylogenetic trees and invalid inferences about relationships among samples [36]. In contrast to the general view, Brotherton et al. assert that cytosine-to-uracil modifications make up the only existing endogenous transitions and that type 1 transitions are merely PCRgenerated artifacts [37]. Having pointed out the disadvantages, it is worth noting that a significant number of the most prominent published studies on aDNA are currently believed to have yielded false-positive results and, thus unauthentic conclusions about the animal origins of sequences on account of their heavy reliance on PCR [3840].

\section{IMPROVING DNA AMPLIFICATION YIELD: THE APPROACHES}

In light of the shortcomings of PCR and the disconcerting failures in getting the picture of aDNA, attempts have been made to alleviate and possibly eliminate the hindrances that take the form of inhibitors and contaminants, lesions, intolerant polymerases, and enzyme-associated difficulties. These efforts have taken various approaches that include, among others, preventing contamination, repairing lesions, and engineering polymerases each tailored to the obstacle(s) one may likely encounter when investigating aDNA. 
The first and the most fundamental approach to ascertaining the quality of endogenous DNA is avoiding its contamination by DNA from external sources. For that purpose, Cooper and Poinar have proposed a set of "nine gold criteria" vital to the authenticity of all aDNA studies whatsoever [41]. Briefly, the nine criteria mandate physical isolation of aDNA laboratories, use of extraction and PCR negative controls, adjustment of PCR amplification strength to suit shorter fragments, quantitation of the target copy number to ensure its sufficiency (>1000), adherence to reproducible results, cloning of amplified products, replication of results in independent laboratories, evaluation of amount and composition of residues like amino acids and fatty acids, and inspection of associated remains for contamination [41]. Although the authors claim that failure to fulfill any one of the criteria would render the outcomes undependable [42], quite a few publications have embraced the guidelines in their entirety $[22,43]$. The majority of the researchers on the other hand, do not seem to be convinced by Cooper et al.'s argument due to its inability to address pre-analysis contamination and, therefore, single out some of the criteria for use in their analyses [23].

The second approach entails tackling the problems brought about by inhibitors and contaminants in order to attain more efficient PCR amplifications. Concerning inhibitors, Hänni and her collaborators have designed a modified DNA extraction procedure that removes the inhibitors (e.g. Maillard products) present in ancient samples $[44,45]$. The technique substitutes isopropanol precipitation for dialysis and centrifugal concentration of the aqueous phase obtained by phenol-chloroform extraction. Conclusively, the reduction in inhibitory activities is indicated by a decline in the intensity of blue fluorescence against an orange fluorescence of DNA in agarose gels [44]. As for contaminants, Boessenkool et al. have adopted an innovative method [46] - originally intended to enhance amplification of food-derived DNA [47] - that aims to ward off potentially contaminating human DNA. The idea principally rests on the use of blocking primers that can hybridize to non-target DNA molecules and, thereby hamper sequence elongation by the virtue of a C3 spacer inserted at their 3' ends [46]. Even though the above two studies are acknowledgeable in their own right as subsidiary protocols, neither does any of them improve upon PCR nor overcome DNA post-mortem degradation in any other way possible.

The third approach focuses on restoring aDNA with the help of damage-specific repair strategies. It seeks to maximize the accessibility of the underlying information of DNA by repairing the destabilizing structural lesions that would otherwise either cause nucleotide misincorporations or hinder amplification by PCR. Enzyme-based methods have been introduced with varying degrees of success [48, 49]. Incubation of aliquots of aDNA samples with uracil-Nglycosylase (UNG) prior to amplification is a tremendously popular remedial measure with respect to DNA degradation. In short, UNG excises deaminated cytosine-turned-uracil residues by breaking the deoxyribose-base bond in deoxyuridine nucleotides [50,51]. Furthermore, it serves as an important tool to verify that the base substitutions in a sample are the result of cytosine deamination [21] and also restrict amplification to undegraded DNA sequences [52].
The scientific history of uracil excision dates back to Tomas Lindahl's pioneering observation of the enzymatic release of uracil from single- and double-stranded DNA molecules, owing to the cleavage of $\mathrm{N}$-glycosidic bonds rather than phosphodiester bonds [48]. What appeared ambiguous in those years is a thoroughly understood process today known as nucleotide flipping that involves a succession of steps, i.e. DNA double-helix distortion, base pair disruption, nucleotide extrusion, and accommodation of the target base in the enzyme pocket [53]. The nucleolytic nature of the mechanism, though, falls through with single-stranded DNA due to the damage it inflicts on the latter's phosphate backbone which exacerbates its fragmentation [8].

Following the same approach, researchers have endeavored to correct the different types of strand breaks and intermolecular cross-links present in aDNA. A considerable number of these attempts have either met middling success, whereas some others have proven quite fruitful. Pusch and his colleagues have proposed a simple reconstructive polymerization method to repair DNA molecules containing single-strand breaks [16]. The method hinges on the presence of priming $3^{\prime}-\mathrm{OH}$ and $5^{\prime} \mathrm{PO}_{4}$ termini available for elongation in overhangs and internal single-stranded regions to obtain amplifiable DNA with an unaltered order of bases. It harnesses DNA polymerase I derived from $E$. coli to synthesize new strands and T4 DNA ligase to seal the nicks [16], and may be accompanied by a pretreatment step with PNK and AP endonuclease I in order to guarantee the presence of the necessary termini [54]. Several studies have utilized the method $[10,55]$ and some have stepped it up to tackle other lesions. Di Bernardo et al. for one have taken advantage of the interstrand cross-links in aDNA and applied polymerization repair to retrieve the respective sequences. Their improved version demands denaturation (heating to $94^{\circ} \mathrm{C}$ for $10 \mathrm{~min}$ ) of aDNA during extraction whereby the molecules lacking cross-links are permanently denatured due to their low concentration, while the cross-linked ones remain partially double-stranded with readily accessible termini [49]. However it still falters when the cross-links occur within PCR target sequences. Among the less supported methods, one can mention treatment of samples with N-phenacylthiazolium bromide (PTB). The latter, in fact, is known to break protein-sugar bonds, and has been used to separate DNA from Maillard products in coprolites [56].

The fourth approach is set to get around the damage rather than to repair it. It principally centers on identifying naturally occurring and creating genetically engineered polymerases possessing low fidelity levels and adept at negotiating lesions. What lies at the root of the quest for more lenient polymerases is the (in)efficiency of $\mathrm{Taq}$ polymerase at bypassing blocking lesions [31, 57]. But, that issue does not arise with the exceptionally accommodating Y-family polymerases that frequently exercise translesion synthesis (TLS) [58]. The members of the family belong to distinctive subfamilies including Rev1, DinB, and UmuC [59] to name a few, that span over all the three domains of life [60]. They share common structural characteristics such as a relatively ample active site [60], a right-hand architecture, an additional little finger (LF) domain for substrate binding [58], and a conserved $\mathrm{N}$-terminal lacking a 
5'-3' exonuclease domain [61]. The type of lesion they come across dictates their mode of operation. An abasic site, for instance, is reoriented into a helical position and the corresponding 5 ' base functions as a template [62]. In an attempt to identify novel Y-polymerases, McDonald et al. probed the members of the Sulfolobaceae family that grow at high temperatures [63] for polymerase IV (a Y-polymerase) homologs using degenerate primers based on archeal Ypolymerase genes such as $d p o 4$ and $d b h[11]$ that were subsequently overexpressed in E. coli and gel-purified [63]. In addition to being thermostable, the isolated enzymes were demonstrated to require dramatically smaller quantities of target DNA and primers, and also augment the recovery of Alu sequences 36- to 45-fold, when used in combination with Taq.

Unlike Y-family polymerases, A-family polymerases stall in the face of lesions because of their less capacious active sites that reject bulky adducts [11]. In spite of that, d'Abbadie et al. have put forth a strategy that makes use of A-family polymerase genes to produce sufficiently processive, selective, and damage-tolerant DNA polymerases [9]. The authors initially recombined polymerase genes encoding $T a q$, Tth, and Tfl by following the staggered extension protocol with common flanking primers and notably short extension intervals to trigger template switching between the homologous regions. In the next major step, they put together a library of chimeric polymerases with the aid of compartmentalized self-replication (by which a polymerase solely replicates its own encoding gene) [64], followed by the amplification of a 47,000-year-old aDNA sample (Ursus spelaeus) using a blend of Taq with a set of the most efficient TLS recombinant polymerases handpicked from the library. Their results in the end were shown to attest to the viability and damage-tolerance of the polymerases. Firstly, the blend could amplify DNA at concentrations below the threshold for Taq to function. Secondly, the blend topped $T a q$ in amplicon yield by an high margin. Finally, the PCR products of the blend came out having a higher incidence of sporadic as well as systematic errors which were indicative of lowered fidelity and enhanced lesion bypass, respectively as compared to Taq alone [9]. This fourth approach only encompasses bypassing hydantoins and abasic sites, and, although rewarding, cannot deal with the wide array of lesions existing in aDNA.

The ceaselessly ongoing research in the field of aDNA continues to push the envelope through not only the application of the four approaches in concert, but also their use in conjunction with other breakthrough techniques. Some of these techniques are, in a nutshell, primer extension capture that uses a single streptavidin-bound primer to spot targeted sequences [65], ${ }^{32} \mathrm{P}$-postlabeling assay involving a trio of steps, i.e. digestion of DNA, radioactive labeling of the individuated nucleotides, and segregation of normal and adducted nucleotides by thin layer chromatography [66, 67], and direct multiplex sequencing that simultaneously incorporates multiplex PCR, sample barcoding, and highthroughput sequencing [68]. Unfortunately, the approaches cited all largely rely on enzymatic reactions, which imply that they are liable to the occasional drawbacks of enzymes. Evidently, the situation calls for an enzyme-free method capable of detecting aDNA quickly and accurately, irrespective of the type or abundance of lesions.

\section{SERRS: THE ULTIMATE REDRESSIVE ACTION}

Drawing upon a non-enzymatic principle, SurfaceEnhanced Resonance Raman Spectroscopy (SERRS) is leaps ahead of its enzymatic counterparts in that it does away with sample preparation, distinguishes the components of a mixture without separation [69], and enjoys unparalleled degrees of sensitivity and specificity [70]. The method is a valuable tool in detecting and quantifying single-stranded [12], and double-stranded DNA [13]. SERRS consists of an important enhancement event, namely surface enhancement which refers to the adsorption of the analyte onto a SERRS substrate (e.g. silver colloids).

The interaction of photons from a monochromatic source of light with matter in any state (so long as it is transparent) results in two kinds of scattering. Rayleigh or elastic scattering is the predominant one that occurs when the incident and transmitted photons have identical energies. Raman or inelastic scattering, on the other hand, is associated with an energy shift such that the scattered photon's energy is either raised (red-shifted) or lowered (blue-shifted), forming Stokes and anti-Stokes bands, respectively. The frequency difference between the incident and the scattered photons is called Raman shift. Raman spectra, plotting intensity vs. Raman shift, show multiple peaks, which depend on the transitions between the rotational, vibrational, and electronic levels of each chemical bond within the scattering molecule. Spectra can therefore be used as identifying fingerprints for detection purposes [71, 72].

The intensity of Raman scattered light is very low compared to that of Rayleigh light $\left(<10^{9}\right)$ [73]. Therefore, researchers have been in a constant exercise to upgrade every component of the equipment. Early on, the attention was invested in improving the light sources, leading to the development of mercury lamps during the 1930s, and later mercury Toronto arc lamps in 1952 [74]. Raman spectroscopy, however, took a turn for the better with the invention of laser sources capable of emitting high-intensity monochromatic radiations in 1960 [75]. Additional advancements came along with the launch of surface-based enhancement in the 1970s and the observation of surfaceenhanced Raman scattering (SERS) by Fleischmann et al. in 1974 [76]. DNA detection is undoubtedly one of the enumerable areas that Raman scattering currently plays a pivotal role in. Established on a Raman signature that depends on the nucleotide composition and sequence of DNA [77], numerous experiments from the detection and identification of a single base [78] and monitoring DNAcisplatin interactions using SERS [79] to the visualization of damaged DNA in sperm cells by Raman microspectroscopy [80] have been successfully performed.

The notion of SERRS was originally conceived by Mullen et al. who used an optical fiber probe and silver colloids to detect metal ions in water [81]. Since then, this very principle that effectively combines resonance Raman and SERS has been appreciably built upon to serve various purposes, and amplify Raman signals up to $10^{14}$ fold [82]. A 
typical SERRS kit includes, but is not restricted to, three chief components: (i) a colloidal metallic substrate, (ii) an aggregator, and (iii) a chromophore.

A suitable SERS-active substrate is a rough metallic surface, and can be found in several forms: electrochemically roughened, nanostructured, or colloidal material [83]. Such a substrate is engineered in order to form clusters of appropriate sizes and shapes, and used at specific values of $\mathrm{pH}[84]$ and frequency of the exciting radiation [83]. The excitation frequency is chosen so that it lines up with the plasmon resonance of the substrate; which is close to its maximum absorption wavelength [14]. Besides, SERS can be explained jointly on the basis of electromagnetic field enhancement (EFE) and the charge-transfer theory (CTT). In accordance with EFE, the robust enhancement of Raman scattering is contingent on the optical properties of the substrate. This is aptly illustrated by the noble metals gold, silver, and copper possessing a single screened s electron which is excited upon irradiation by visible light, thus, intensifying polarization and generating resonance [81]. CTT, which is the minor contributor, highlights the formation of bonds between the lone pair of the molecule of interest and the substrate and thereby projects a unified image of the two in which charge transitions are possible [85]. Although mostly monopolized by noble metals, surface enhancement has been achieved using transition metals such as $\mathrm{Ni}, \mathrm{Fe}, \mathrm{Co}$, and $\mathrm{Rh}$ [86]. The earliest strategy called 'borrowing SERS' involved electrodepositing an ultrathin layer (3-10 atomic layers) of transition metals on active substrates [87]. Its major downside was the appearance of pinholes in the overlayer. In addition to eliminating the pinholes [88], researchers have come up with other unique strategies, for example the use of Pt nanoaggregates in lieu of aggregated colloids [89]. Nanoparticles remain the standard substrate, for they effortlessly get excited in the visible spectrum. When it comes to detecting DNA, silver and gold nanoparticles emerge as the most preferred substrates [90]. In order to gain further amplification of the signal, nanoparticles can be aggregated in clusters, thus creating hotspots of amplification [91]. Aggregating agents have been developed with a view to promoting aggregation among nanoparticles in a substrate-specific manner [83]. In the case of DNA, spermine $\left(\mathrm{NH}_{2}-\left[\mathrm{CH}_{2}\right]_{3}-\mathrm{NH}-\left[\mathrm{CH}_{2}\right]_{4}-\mathrm{NH}-\right.$ $\left.\left[\mathrm{CH}_{2}\right]_{3}-\mathrm{NH}_{2}\right)$, a naturally occurring tetramine, is frequently used as an aggregating agent that has been recognized as the strongest in terms of signal enhancement [69]. Besides getting nanoparticles together, spermine encourages DNAsubstrate interactions by neutralizing the negatively charged phosphate groups of the nucleotides. This will, in effect, abolish the repulsion acting between DNA and the similarly charged silver nanoparticles [92].

A crucial element that distinguishes SERRS from SERS is the resonance provided by chromophoric labeling dyes, allowing massive amplifications. Dyes are attached to singlestranded DNA sequences. Since the dye molecules are electrically charged, selecting a dye to work with is a very critical decision. Considering both DNA and the substratewhether it be silver or gold - are negatively charged, one is bound to label the probes either with a positively charged dye such as rhodamine 6G (R6G) or with a negatively charged dye (e.g. HEX, ROX, etc.) modified with propargyl amine [14]. Specific detection of labeled single-stranded DNA sequences have been achieved by Graham et al., reaching very low limits of detection of $10^{-12} \mathrm{M}$ [93], close to the realities of PCR amplification. Labeled single-stranded DNA sequences can be further used as detection probes in order to detect specific DNA sequences [94]. Specific hybridization of the probes (in accord with the rules of complementarity) to the DNA molecules under analysis puts up the platform for the detection of the latter based on the Raman signature of the dye [94, 95].

\section{A NOVEL SERRS SANDWICH-HYBRIDIZATION ASSAY: A DEEP MOLECULAR EXCAVATION}

Feuillie, Merheb et al. have developed an enzyme-free strategy anchored in the principles of SERRS to look into aDNA inside-out. In their first step toward developing a fullfledged specific DNA detection method, they have outlined an approach to detecting single-stranded nucleic acids sequences [12]. Two short oligonucleotide probes hybridize to target DNA, a 22-mer detection probe labeled with RG6 hybridizes to the 3 'end, and a 20-mer capture probe tagged with biotin hybridizes to the 5 'end of the target. The target molecules are subsequently immobilized by strepdavidincoated magnetic microbeads that latch onto the biotin labels. Using magnetic separation, the uncaught molecules are totally washed off. Finally the target-probe duplexes are denatured through heating at $95^{\circ} \mathrm{C}$ for $20 \mathrm{~min}$, and the detection probes are retrieved for measurement by SERRS. The Raman signal of R6G comprising 9 peaks with the most intense lying at $1650 \mathrm{~cm}^{-1}$ indicates the presence of the target DNA sequence. The system's specificity was tested with 2 closely related sequences of Rupicapra rupicapra and Capra hircus. Only the samples, which contained $R$. rupicapra presented a SERRS signal of R6G in the end, thus validating the specificity of the assay. Furthermore, the quantitative aspect of the method was showcased by the linear relationship between the initial concentration of the target DNA and the ratio of the area under the peak at $1650 \mathrm{~cm}^{-1}$ to acquisition time [12]. With a well demonstrated potential as an alternative to PCR, the method of sandwich-hybridization has been expanded upon to go beyond detecting only singlestranded DNA. Feuillie, Merheb et al. [13] applied the SERRS-hybridization assay to the detection of doublestranded DNA. With double-stranded targets, the strands of each duplex ought to be kept apart so that the probes could hybridize with either of them. Short species-specific oligonucleotides called blocker, were introduced, and are aimed at hybridizing to a strand of DNA, thus precluding it from joining with the other. These are used in excess of target concentrations by 3 orders of magnitude in order to make sure every single molecule in the sample contributes to the Raman signal. Absence of blockers drastically downgrade the intensity of the signal as large proportions of the targets will not be secured for SERRS analysis. Moreover, SERRS allows the simultaneous specific detection and quantification of two double-stranded DNA targets [13]. The targets namely, a $92 \mathrm{bp}$ mitochondrial DNA sequence of $R$. rupicapra (chamois) and an orthologous 91 bp sequence of goat, were studied in varying proportions ranging from $0 \%$ to $100 \%$ so as to comment on both the qualitative and quantitative aspects of the method. Targets 
were hybridized to 2 probes, a capture probe labeled with streptavidin, similar for both targets, and a detection probe labeled with either R6G or HEX for the sequences of chamois and goat, respectively. Following the four basic steps of hybridization, immobilization, washing, and elution, the mixtures were analyzed by SERRS using a $514.5 \mathrm{~nm}$ excitation wavelength. Samples containing either only goat or only chamois DNA were identified with HEX and R6G signatures, respectively, whereas those containing both were found to give off a multiplexed signal with sharp peaks.

\section{APPLICATIONS: A PRAGMATIC SPOTLIGHT ON SERRS}

A discussion on SERRS would not do its subject justice without a mention of the diverse applications it offers. As an alternative to PCR and other similar techniques, the method of SERRS presents an opportunity to dig deeper into DNA molecules found in trace amounts or terribly degraded for a variety of purposes that include detecting aDNA, cancer, and food frauds [96], determining the existing state of a disease [97], and other DNA-centered investigations. The ability to detect DNA fragments lies at the heart of these inquiries. Cancer diagnosis by SERRS may proceed through different pathways depending upon the target. Detection of specific DNA sequences and single-nucleotide polymorphisms is one such pathway [98] that relies on the specific hybridization of probes to target genes. HIV [99] and breast cancer [100] have been diagnosed using this method targeting the gag gene of human immunodeficiency virus and breast cancer susceptibility gene 1 (BRCA1), respectively. Disease state analysis benefits from the quenching of fluorescence by the substrate and the discerning sensitivity of SERRS in detecting multiple dye labels (hence multiple species) [101] to identify infectious diseases or tell them apart. Detection of Chlamydia and Gonorrhea in urine by means of a SERRSbased DNA assay has been reported by Faulds and others who further went on to exploring the possibility of analyzing more targets [102]. Although the principal focus of the present review is on DNA, it would be helpful to know that SERRS could tap into proteins, nonetheless. Characterizing the synthetic dyes in pen inks [103], comprehending the events that follow ink absorption onto paper [104], studying the redox chemistry of cytochrome c [105], and detecting viral pathogens by antibodies [106] are among the playgrounds of SERRS where DNA is barely involved.

\section{CONCLUSION: AN EYE-OPENING FLASHBACK}

Ancient DNA marks the point where archeology meets genetics. It is a bountiful reservoir of genetic information with countless historical tales to recount. The conditions that prevail in dead cells, however, stand in the way of aDNA through wreaking damage on it. As a result, the DNA is afflicted with blocking lesions and nucleotide misincorporations. The techniques that were implemented at the outset such as PCR and bacterial cloning did not take the issue of DNA degradation into serious consideration, and yielded results whose authenticity is said to be in question. To improve DNA retrieval, both quality- and quantity-wise, a series of approaches has been formulated to prevent contamination, dispose of inhibitors, repair degraded DNA, and bypass blocking lesions by damage-tolerant polymerases. But even so the aDNA research has stumbled upon the complications of using enzyme-based methods. SERRS, on the other hand, is a biophysical, non-enzymatic method, that also exhibits high degrees of sensitivity. Feuillie, Merheb et al. have developed a SERRShybridization assay capable of detecting single-stranded, double-stranded, and significantly degraded DNA molecules with specificity. It consists of a colloidal substrate, an aggregating agent, and a dye label, and depends upon a combination of resonance and surface enhancement to specifically detect DNA sequences despite the degradation and damages undergone by the DNA molecules.

\section{CONFLICT OF INTEREST}

The authors confirm that this article content has no conflicts of interest.

\section{ACKNOWLEDGEMENTS}

Declared none.

\section{REFERENCES}

[1] Rizzi E, Lari M, Gigli E, De Bellis G, Caramelli D. Ancient DNA studies: new perspectives on old samples. Genet Select Evol 2012; 44: 21 .

[2] Ermini L, Olivieri C, Rizzi E, et al. Complete mitochondrial genome sequence of the Tyrolean Iceman. Curr Biol 2008 18: 1687-93.

[3] Willerslev E, Cooper A. Ancient DNA. Proceedings Biological sciences / The Royal Society 2005; 272: 3-16.

[4] Hoss M, Jaruga P, Zastawny TH, Dizdaroglu M, Paabo S. DNA damage and DNA sequence retrieval from ancient tissues. Nucl Acid Res 1996; 24: 1304-7.

[5] Paabo S. Ancient DNA: Extraction, characterization, molecular cloning, and enzymatic amplification. Proc Natl Acad Sci U.S.A. 1989; 86: 1939-43.

[6] Fromenty B, Demeilliers C, Mansouri A, Pessayre D. Escherichia coli exonuclease III enhances long PCR amplification of damaged DNA templates. Nucl Acid Res 2000; 28: E50.

[7] Briggs AW, Good JM, Green RE, et al. Targeted retrieval and analysis of five Neandertal mtDNA genomes. Science 2009; 325: 318-21.

[8] Mitchell D, Willerslev E, Hansen A. Damage and repair of ancient DNA. Mutat Res 2005; 571: 265-76.

[9] d'Abbadie M, Hofreiter M, Vaisman A, et al. Molecular breeding of polymerases for amplification of ancient DNA. Nat Biotech 2007; 25: 939-43.

[10] Heyn P, Stenzel U, Briggs AW, Kircher M, Hofreiter M, Meyer M. Road blocks on paleogenomes--polymerase extension profiling reveals the frequency of blocking lesions in ancient DNA. Nucl Acid Res 2010; 38: e161.

[11] McDonald JP, Hall A, Gasparutto D, Cadet J, Ballantyne J, Woodgate R. Novel thermostable Y-family polymerases: applications for the PCR amplification of damaged or ancient DNAs. Nucl Acid Res 2006; 34: 1102-11.

[12] Feuillie C, Merheb MM, Gillet B, Montagnac G, Daniel I, Hanni C A novel SERRS sandwich-hybridization assay to detect specific DNA target. PloS one 2011; 6: e17847.

[13] Feuillie C, Merheb MM, Gillet B, Montagnac G, Hanni C, Daniel I. Enzyme-free detection and quantification of double-stranded nucleic acids. Anal Bioanal Chem 2012; 404: 415-22.

[14] Graham D, Smith WE, Linacre AMT, Munro CH, Watson ND, White PC. Selective detection of deoxyribonucleic acid at ultralow concentrations by SERRS. Analy Chem 1997; 69: 4703-7.

[15] Darzynkiewicz Z, Juan G, Li X, Gorczyca W, Murakami T, Traganos F. Cytometry in cell necrobiology: analysis of apoptosis and accidental cell death (necrosis). Cytom 1997; 27: 1-20. 
[16] Pusch CM, Giddings I, Scholz M. Repair of degraded duplex DNA from prehistoric samples using Escherichia coli DNA polymerase I and T4 DNA ligase. Nucl Acid Res 1998; 26: 857-9.

[17] Molak M, Ho SY. Evaluating the impact of post-mortem damage in ancient DNA: A theoretical approach. J Mol Evol 2011; 73: 24455.

[18] Dizdaroglu M. Oxidative damage to DNA in mammalian chromatin. Mut Res 1992; 275: 331-42.

[19] Greenberg MM. DNA interstrand cross-links from modified nucleotides: Mechanism and application. Nucl Acid Symp Ser 2005: 57-8.

[20] Sinha RP, Hader DP. UV-induced DNA damage and repair: a review. Photochem photobiol Sci: 2002; 1: 225-36.

[21] Hofreiter M, Jaenicke V, Serre D, von Haeseler A, Paabo S. DNA sequences from multiple amplifications reveal artifacts induced by cytosine deamination in ancient DNA. Nucl Acid Res 2001; 29: 4793-9.

[22] Bunce M, Szulkin M, Lerner HR, et al. Ancient DNA provides new insights into the evolutionary history of New Zealand's extinct giant eagle. PLoS Biol 2005; 3: e9.

[23] Gilbert MT, Bandelt HJ, Hofreiter M, Barnes I. Assessing ancient DNA studies. Trend Ecol Evol 2005; 20: 541-4.

[24] Jones M. The Molecule Hunt: Archeology and the Search for Ancient DNA Arcade Publishing; 2002.

[25] Higuchi R, Bowman B, Freiberger M, Ryder OA, Wilson AC. DNA sequences from the quagga, an extinct member of the horse family. Nature 1984; 312: 282-4.

[26] Paabo S. Molecular cloning of Ancient Egyptian mummy DNA. Nature 1985; 314: 644-5.

[27] Mullis KB, Faloona FA. Specific synthesis of DNA in vitro via a polymerase-catalyzed chain reaction. Meth Enzymol 1987; 155: 335-50.

[28] Powledge TM. The polymerase chain reaction. Adv Physiol Ed 2004; 28 : 44-50.

[29] Stiller M, Green RE, Ronan M, et al. Patterns of nucleotide misincorporations during enzymatic amplification and direct largescale sequencing of ancient DNA. Proc Natl Acad Sci U.S.A. 2006; 103: $13578-84$.

[30] Takeshita M, Chang CN, Johnson F, Will S, Grollman AP. Oligodeoxynucleotides containing synthetic abasic sites. Model substrates for DNA polymerases and apurinic/apyrimidinic endonucleases. J Biol Chem 1987; 262: 10171-9.

[31] Sikorsky JA, Primerano DA, Fenger TW, Denvir J. DNA damage reduces Taq DNA polymerase fidelity and PCR amplification efficiency. Biochem Biophys Res Commun 2007; 355: 431-7.

[32] Lamers R, Hayter S, Matheson CD. Postmortem miscoding lesions in sequence analysis of human ancient mitochondrial DNA. J Mol Evol 2009; 68: 40-55.

[33] Gilbert MT, Hansen AJ, Willerslev E, et al. Characterization of genetic miscoding lesions caused by postmortem damage. Am J Human Gen 2003; 72: 48-61.

[34] Briggs AW, Stenzel U, Johnson PL, et al. Patterns of damage in genomic DNA sequences from a Neandertal. Proc Natl Acad Sci U.S.A. 2007; 104: 14616-21.

[35] Gilbert MT, Binladen J, Miller W, et al. Recharacterization of ancient DNA miscoding lesions: insights in the era of sequencingby-synthesis. Nucl Acid Res 2007; 35: 1-10.

[36] Axelsson E, Willerslev E, Gilbert MT, Nielsen R. The effect of ancient DNA damage on inferences of demographic histories. Mol Biol Evol 2008; 25: 2181-7.

[37] Brotherton P, Endicott P, Sanchez JJ, et al. Novel high-resolution characterization of ancient DNA reveals C > U-type base modification events as the sole cause of post mortem miscoding lesions. Nucl Acid Res 2007; 35: 5717-28.

[38] Handt O, Krings M, Ward RH, Paabo S. The retrieval of ancient human DNA sequences. Am J Human Gen 1996; 59: 368-76.

[39] Woodward SR, Weyand NJ, Bunnell M. DNA sequence from Cretaceous period bone fragments. Science 1994; 266 :1229-32.

[40] Zischler H, Hoss M, Handt O, von Haeseler A, van der Kuyl AC, Goudsmit J. Detecting dinosaur DNA. Science 1995; 268: 1192-3.

[41] Cooper A, Poinar HN. Ancient DNA: do it right or not at all. Science 2000; 289: 1139.

[42] Green RE, Briggs AW, Krause J, Prufer K, Burbano HA, Siebauer $\mathrm{M}$, et al. The Neandertal genome and ancient DNA authenticity. EMBO J 2009; 28: 2494-502.
[43] Caramelli D, Lalueza-Fox C, Vernesi C, et al. Evidence for a genetic discontinuity between Neandertals and 24,000-year-old anatomically modern Europeans. Proc Natl Acad Sci U.S.A. 2003; 100: 6593-7.

[44] Hanni C, Brousseau T, Laudet V, Stehelin D. Isopropanol precipitation removes PCR inhibitors from ancient bone extracts. Nucl Acids Res 1995; 23: 881-2.

[45] Kalmar T, Bachrati CZ, Marcsik A, Rasko I. A simple and efficient method for PCR amplifiable DNA extraction from ancient bones. Nucl Acids Res 2000; 28: E67.

[46] Boessenkool S, Epp LS, Haile J, et al. Blocking human contaminant DNA during PCR allows amplification of rare mammal species from sedimentary ancient DNA. Mol Ecol 2012; 21: $1806-15$

[47] Vestheim H, Jarman SN. Blocking primers to enhance PCR amplification of rare sequences in mixed samples - a case study on prey DNA in Antarctic krill stomachs. Fron Zool 2008; 5: 12.

[48] Lindahl T. An N-glycosidase from Escherichia coli that releases free uracil from DNA containing deaminated cytosine residues. Proc Natl Acad of Sci U.S.A. 1974; 71: 3649-53.

[49] Di Bernardo G, Del Gaudio S, Cammarota M, Galderisi U, Cascino A, Cipollaro M. Enzymatic repair of selected cross-linked homoduplex molecules enhances nuclear gene rescue from Pompeii and Herculaneum remains. Nucl Acids Res 2002; 30: e16.

[50] Kim YJ, Wilson DM, $3^{\text {rd }}$. Overview of base excision repair biochemistry. Curr Mol Pharmacol 2012; 5: 3-13.

[51] Briggs AW, Good JM, Green RE, et al. Targeted Retrieval and Analysis of Five Neandertal mtDNA Genomes. Science 2009; 325: 318-21.

[52] Johnson SS, Hebsgaard MB, Christensen TR, et al. Ancient bacteria show evidence of DNA repair. Proc Natl Acad of Sci U.S.A. 2007; 104: 14401-5.

[53] David SS, O'Shea VL, Kundu S. Base-excision repair of oxidative DNA damage. Nature 2007; 447: 941-50.

[54] Hansen AJ, Mitchell DL, Wiuf C, et al. Crosslinks rather than strand breaks determine access to ancient DNA sequences from frozen sediments. Genetics 2006; 173: 1175-9.

[55] Iniguez AM, Araujo A, Ferreira LF, Vicente AC. Analysis of ancient DNA from coprolites: a perspective with random amplified polymorphic DNA-polymerase chain reaction approach. Memorias do Instituto Oswaldo Cruz 2003; 98 Suppl 1: 63-5.

[56] Poinar HN, Hofreiter M, Spaulding WG, et al. Molecular coproscopy: dung and diet of the extinct ground sloth Nothrotheriops shastensis. Science 1998; 281: 402-6.

[57] Wellinger RE, Thoma F. Taq DNA polymerase blockage at pyrimidine dimers. Nucl Acid Res 1996; 24: 1578-9.

[58] Ohmori H, Hanafusa T, Ohashi E, Vaziri C. Separate roles of structured and unstructured regions of Y-family DNA polymerases. Adv Pro Chem Struct Biol 2009; 78: 99-146.

[59] Ohmori H, Friedberg EC, Fuchs RP, et al. The Y-family of DNA polymerases. Mol cell 2001; 8: 7-8.

[60] Sale JE, Lehmann AR, Woodgate R. Y-family DNA polymerases and their role in tolerance of cellular DNA damage. Nat Rev Mol Cell Biol 2012; 13: 141-52.

[61] Yang Z, Sismour AM, Sheng P, Puskar NL, Benner SA. Enzymatic incorporation of a third nucleobase pair. Nucl Acid Res 2007; 35 4238-49.

[62] Ling H, Boudsocq F, Woodgate R, Yang W. Snapshots of replication through an abasic lesion; structural basis for base substitutions and frameshifts. Mol Cell 2004; 13: 751-62.

[63] Boudsocq F, Iwai S, Hanaoka F, Woodgate R. Sulfolobus solfataricus P2 DNA polymerase IV (Dpo4): an archaeal DinB-like DNA polymerase with lesion-bypass properties akin to eukaryotic polๆ. Nucl Acid Res 2001; 29: 4607-16.

[64] Ghadessy FJ, Ong JL, Holliger P. Directed evolution of polymerase function by compartmentalized self-replication. Proc Natl Acad Sci U.S.A. 2001; 98: 4552-7.

[65] Briggs AW, Good JM, Green RE, et al. Primer extension capture: targeted sequence retrieval from heavily degraded DNA sources. J Visual Exp : JoVE 2009: 1573.

[66] Phillips DH. Detection of DNA modifications by the $32 \mathrm{P}$ postlabelling assay. Mut Res 1997; 378: 1-12.

[67] Jones NJ. (3)(2)P-postlabelling for the sensitive detection of DNA adducts. Meth Mol Biol (Clifton, NJ) 2012; 817: 183-206.

[68] Stiller M, Knapp M, Stenzel U, Hofreiter M, Meyer M. Direct multiplex sequencing (DMPS)--a novel method for targeted high- 
throughput sequencing of ancient and highly degraded DNA. Gen Res 2009; 19: 1843-8.

[69] Macaskill A, Chernonosov AA, Koval VV, et al. Quantitative surface-enhanced resonance Raman scattering of phthalocyaninelabelled oligonucleotides. Nucl Acid Res 2007; 35: e42.

[70] Faulds K, Jarvis R, Smith WE, Graham D, Goodacre R. Multiplexed detection of six labelled oligonucleotides using surface enhanced resonance Raman scattering (SERRS). Anal 2008; 133: 1505-12.

[71] Wachsmann-Hogiu S, Weeks T, Huser T. Chemical analysis in vivo and in vitro by Raman spectroscopy--from single cells to humans. Curr Op Biotech 2009; 20: 63-73.

[72] Zavaleta CL, Kircher MF, Gambhir SS. Raman's "effect" on molecular imaging. J Nucl Med : official publication, Society of Nuclear Medicine 2011; 52: 1839-44.

[73] Weber WH, Merlin R. Raman Scattering in Materials Science: U.S. Government Printing Office; 2000.

[74] Welsh HL, Crawford MF, Thomas TR, Love GR. raman spectroscopy of low pressure gases and vapors. Canad J Phys 1952; 30: 577-96.

[75] de Metz J. Optical design of a laser system for nuclear fusion research. Applied optics 1971; 10: 1609-14.

[76] Fleischmann M, Hendra PJ, McQuillan AJ. Raman spectra of pyridine adsorbed at a silver electrode. Chem Phys Lett 1974; 26: 163-6.

[77] Deng H, Bloomfield VA, Benevides JM, Thomas GJ, Jr. Dependence of the Raman signature of genomic B-DNA on nucleotide base sequence. Biopolymers 1999; 50: 656-66.

[78] Kneipp K, Kneipp H, Kartha VB, et al. Detection and identification of a single DNA base molecule using surface-enhanced Raman scattering (SERS). Phys Rev E 1998; 57: R6281-R4.

[79] Barhoumi A, Zhang D, Tam F, Halas NJ. Surface-enhanced Raman spectroscopy of DNA. J Am Chem Soc 2008; 130: 5523-9.

[80] Mallidis C, Wistuba J, Bleisteiner B, et al. In situ visualization of damaged DNA in human sperm by Raman microspectroscopy. Human Reprod 2011; 26: 1641-9.

[81] Mullen KI, Wang D, Crane LG, Carron KT. Trace Detection of Ionic Species with Surface Enhanced Raman Spectroscopy. Spectroscopy 1992; 7: 24-31.

[82] Nie S, Emory SR. Probing single molecules and single nanoparticles by surface-enhanced Raman scattering. science 1997; 275: $1102-6$

[83] Kneipp J, Kneipp H, Wittig B, Kneipp K. One- and two-photon excited optical ph probing for cells using surface-enhanced Raman and hyper-Raman nanosensors. Nano Lett 2007; 7: 2819-23.

[84] Shadi IT, Cheung W, Goodacre R. Quantitative analysis of methyl green using surface-enhanced resonance Raman scattering. Anal Bioanal Chem 2009; 394: 1833-8.

[85] Lombardi JR, Birke RL, Lu T, Xu J. Charge-transfer theory of surface enhanced Raman spectroscopy: Herzberg-Teller contributions. J Chem Phys 1986; 84: 4174-80.

[86] Ren B, Liu G-K, Lian X-B, Yang Z-L, Tian Z-Q. Raman spectroscopy on transition metals. Anal Bioanal Chem 2007; 388: $29-45$.

[87] Park S, Yang P, Corredor P, Weaver MJ. Transition metal-coated nanoparticle films: vibrational characterization with surfaceenhanced Raman scattering. J Am Chem Soc 2002; 124: 2428-9.

[88] Mrozek MF, Xie Y, Weaver MJ. Surface-enhanced Raman scattering on uniform platinum-group overlayers: Preparation by redox replacement of underpotential-deposited metals on gold. Anal Chem 2001; 73: 5953-60.

[89] Kim NH, Kim K. Surface-enhanced resonance Raman scattering of rhodamine 6G on Pt nanoaggregates. J Raman Spec 2005; 36: 6238.

[90] Stokes RJ, Macaskill A, Lundahl PJ, Smith WE, Faulds K, Graham D. Quantitative enhanced Raman scattering of labeled DNA from gold and silver nanoparticles. Small (Weinheim an der Bergstrasse, Germany) 2007; 3: 1593-601.

[91] Halvorson RA, Vikesland PJ. Surface-enhanced Raman spectroscopy (SERS) for environmental analyses. Environ Sci Tech 2010; 44: 7749-55.

[92] Basu HS, Marton LJ. The interaction of spermine and pentamines with DNA. The Biochem J 1987; 244: 243-6.

[93] Graham D, Faulds K. Quantitative SERRS for DNA sequence analysis. Chem Soc Rev 2008; 37: 1042-51.

[94] Vo-Dinh T, Houck K, Stokes DL. Surface-enhanced Raman gene probes. Anal Chem 1994; 66: 3379-83.

[95] Treffer R, Deckert V. Recent advances in single-molecule sequencing. Curr Opinion Biotech 2010; 21: 4-11.

[96] Teletchea F, Maudet C, Hanni C. Food and forensic molecular identification: update and challenges. Trends in Biotech 2005; 23 : 359-66.

[97] McNay G, Eustace D, Smith WE, Faulds K, Graham D. Surfaceenhanced Raman scattering (SERS) and surface-enhanced resonance Raman scattering (SERRS): A review of applications. Appl Spec 2011; 65: 825-37.

[98] Vendrell M, Maiti KK, Dhaliwal K, Chang YT. Surface-enhanced Raman scattering in cancer detection and imaging. Trends in Biotech 2013; 31: 249-57.

[99] Culha M, Stokes D, Allain LR, Vo-Dinh T. Surface-enhanced Raman scattering substrate based on a self-assembled monolayer for use in gene diagnostics. Anal Chem 2003; 75: 6196-201.

[100] Isola NR, Stokes DL, Vo-Dinh T. Surface-enhanced Raman gene probe for HIV detection. Anal Chem 1998; 70: 1352-6.

[101] Faulds K, Smith WE, Graham D. Evaluation of surface-enhanced resonance Raman scattering for quantitative DNA analysis. Anal Chem 2004; 76: 412-7.

[102] Faulds K, Fruk L, Robson DC, et al. A new approach for DNA detection by SERRS. Faraday discussions 2006; 132: 261-8; discussion 309-19.

[103] Geiman I, Leona M, Lombardi JR. Application of Raman spectroscopy and surface-enhanced Raman scattering to the analysis of synthetic dyes found in ballpoint pen inks. J Forens Sci 2009; 54: 947-52.

[104] Littleford RE, Hughes MP, Dent G, Tackley D, Smith WE. Surface-enhanced resonance Raman scattering of black inkjet dyes in solution and in situ printed onto paper. Appl Spec 2003; 57: 977 83 .

[105] Murgida DH, Hildebrandt P, Wei J, He YF, Liu H, Waldeck DH Surface-Enhanced Resonance Raman Spectroscopic and electrochemical study of cytochrome $\mathrm{c}$ bound on electrodes through coordination with pyridinyl-terminated self-assembled monolayers. J Phys Chem B 2004; 108: 2261-9.

[106] Driskell JD, Kwarta KM, Lipert RJ, Porter MD, Neill JD, Ridpath JF. Low-level detection of viral pathogens by a surface-enhanced Raman scattering based immunoassay. Anal Chem 2005; 77: 6147 54 .

(c) Soleimani et al; Licensee Bentham Open.

This is an open access article licensed under the terms of the Creative Commons Attribution Non-Commercial License (http://creativecommons.org/licenses/ by-nc/3.0/) which permits unrestricted, non-commercial use, distribution and reproduction in any medium, provided the work is properly cited. 